\title{
PERANAN ZAKAT SEBAGAI PENGURANG PENGHASILAN KENA PAJAK DI KANTOR KEMENTERIAN AGAMA KABUPATEN GOWA
}

\author{
Oleh: \\ Thamrin Logawali, Sitti Aisyah, Kamaruddin dan Nurfiah Anwar \\ UIN Alauddin Makassar \\ e-mail: thamrin.logawali@uin-alauddin.ac.id, \\ sittiaisyahsulaiman@yahoo.co.id, kamaruddin46@gmail.com,dan \\ nurfiahanwar05@gmail.com
}

\begin{abstract}
ABSTRAK
Permasalahan dalam judul penelitian ini bagaimana peranan zakat sebagai pengurang Penghasilan Kena Pajak di Kantor Kementrian Agama Kabupaten Gowa, dan tujuan penelitian ini adalah untuk mengetahui peranan zakat dalam kehidupan masyarakat dalam hubungannya dengan pengurang penghasilan kena pajak di Kantor Kementerian Agama Kabupaten Gowa.

Penelitian ini menggunakan metode penelitian yang bersifat kualitatif dengan pendekatan normatif dan sosiologis. Adapun sumber data penelitian ini adalah pihak Bimbingan Islam (BIMAS) di kantor Kementrian Agama kabupaten Gowa. Selanjutnya, metode pengumpulan data yang digunakan adalah observasi, wawancara, dokumentasi dan penelusuran referensi. Setelah data terkumpul maka dilakukan tekhnik pengelolaan data dengan melalui tiga tahapan, yaitu : reduksi data, penyajian data dan penarikan kesimpulan.

Hasil penelitian ini menunjukkan bahwa penerapan zakat sebagai pengurang Penghasilan Kena Pajak di Kantor Kementerian Agama Kabupaten Gowa memberikan keringanan kepada ummat Islam dalam membayar zakat dan pajak juga meningkatkan kesadaran dan kejujuran dalam diri masyarakat untuk membayar zakat, hal ini berdampak baik pada pendapatan negara.

Implikasi dari penelitian ini adalah pihak dari Kementerian Agama Kabupaten Gowa sebagai pihak pemerintah diharapkan agar melakukan koordinasi dengan pemerintah kabupaten gowa agar mengusahakan untuk terciptanya undang-undang atau kebijakan pemerintah tentang zakat sebagai pengurang langsung pajak penghasilan seperti pengelolaan zakat yang telah diterapkan berdasarkan perinsip Islam.
\end{abstract}

Kata Kunci: Zakat; pengurang; pajak 


\section{PENDAHULUAN}

Zakat lama di salah pahami seakan "hanya merupakan amal pribadi saja yang sifatnya sukarela, padahal zakat merupakan sumber penerimaan negara terbesar pada awal sejarah Islam."1 Namun di tengah menguatnya pajak dalam penerimaan Negara, secara bersamaan muncul sebuah kesadaran ummat Islam akan peranan zakat. Dua hal ini menuntut adanya pengelolaan yang tepat, untuk tidak menimbulkan efek kontra produktif dalam pembangunan nasional. Salah satunya yaitu "beban ganda atas kewajiban untuk membayar pajak dan zakat."2

Zakat salah satu rukun Islam yang kewajibannya bersifat mutlak atas harta kekayaan seseorang menurut aturan yang telah di tetapkan dalam alQur'an dan Hadis. Dalam konteks Negara modern, zakat bukanlah pajak yang merupakan salah satu sumber pendapatan Negara. Zakat di pandang sebagai sarana komunikasi utama antara orang kaya dengan orang miskin, yang memiliki peranan sangat penting sebagai sarana distribusi penghasilan dalam menata tata kehidupan bermasyarakat yang sejahtera, berkeadilan di dalam sebuah Negara.

Kedudukan zakat dalam Islam suatu keunggulan dalam sistem ekonomi Islam. Zakat menggambarkan perwujudan ketaatan seorang muslim terhadap Sang Khaliq. Hal ini merupakan suatu penjelmaan dari solidaritas seorang muslim dalam kehidupan bermasyarakat. Jadi jika shalat berusaha membentuk keshalehan pribadi individu, maka zakat berperan membentuk keshalehan sosial bagi setiap individu dalam masysrakat.

Korelasi antara zakat dan pajak sama-sama mempunyai fungsi pemungutan dalam kehidupan bernegara. Pada zakat, fungsi pemungutan

\footnotetext{
${ }^{1}$ Afif Noor, Hubungan Zakat dengan Pajak dalam Undang-Undang No.38 Tahun 1999 (Semarang : Universitas Diponegoro, 2003), h. 3

${ }^{2}$ Damanhur. Mewujudkan Sistem Perpajakan Perspektif Islam (Banda Aceh Darussalam : Prosiding Persidangan Antar bangsa Pembangunan Aceh, 2006) h. 24
} 
dapat dilakukan oleh orang yang terkena kewajiban membayar zakat dan dapat langsung disalurkan kepada orang yang berhak menerimanya atau dilakukan oleh suatu badan atau lembaga resmi seperti Badan Amil Zakat (BAZ) atau Lembaga Amil Zakat (LAZ) yang di bentuk oleh pemerinta untuk memungut zakat serta mendistribusikan kepada delapan golongan yang berhak menerima zakat. Sedangkan dalam pajak, fungsi pemungutannya dilakukan oleh Negara melalui Dirjen Pajak. Menurut ajaran Islam, zakat sebaiknya di pungut oleh Negara dan atas nama pemerintah yang bertindak sebagai wakil fakir miskin.

Fakta bahwa subjek pajak terbesar adalah kaum muslim yang jumlahnya $87 \%$ dari total penduduk Indonesia, pemerintah berupaya untuk meminimalkan kewajiban ganda yang memberatkan. Untuk mengatasinya dilakukan upaya titik temu antara pajak dan zakat sehingga kedua kewajiban tersebut dapat dilaksanakan oleh ummat Islam tanpa memberatkannya. Pemerintah membuat aturan yang dapat menjadi solusi bagi kewajiban ganda yaitu zakat dan pajak yang dialami oleh ummat Islam. Hal ini dicantumkan dalam pasal 22 UU No.23 Tahun 2011 atas perubahan pasal 14 ayat (3) UU No.38 tahun 1999 Tentang Pengelolaan Zakat, disebutkan:

Zakat yang telah dibayarkan kepada badan amil zakat atau lembaga amil zakat dikurangkan dari laba/pendapatan sisa kena pajak dari Wajib Pajak yang bersangkutan sesuai dengan peraturan perundang-undangan yang berlaku.

Undang-undang ini menunjukkan bahwa pemerintah mencoba untuk berperan aktif dalam menciptakan pelaksanaan kewajiban keagamaan masyara-katnya dengan menjadikan unsur zakat sebagai salah satu tax relief (keringanan pajak) dalam pemungutan Pajak Penghasilan (PPh) di Indonesia. Saat ini undang-undang menjadikan zakat sebagai salah satu faktor pengurang penghasilan neto Wajib Pajak Orang Pribadi (WPOP) dalam menentukan besarnya Penghasilan Kena Pajak. Hal ini diharapkan dapat meminimalkan beban ganda yang di pikul oleh ummat Islam sebagai Wajib Pajak dan muzakki. Jika di lihat dari fungsi dasarnya membayar zakat bisa disamakan nilainya 
Thamrin: Zakat; pengurang; pajak

dengan membayar pajak yakni sama-sama dimaksudkan untuk melaksanakan kewajiban yang bertujuan untuk kemaslahatan ummat dan bangsa. Melihat kenyataan di atas, bahwa pemerintah telah mengeluarkan undang-undang sebagai solusi dari beban ganda yang dirasakan ummat Islam yang saat ini belum terealisasi dengan baik dan besarnya potensi dana zakat di Indonesia, maka peneliti tertarik meneliti tentang "Peranan Zakat Sebagai Pengurang Penghasilan Kena Pajak" dalam instansi pemerintah.

\section{KAJIAN PUSTAKA}

\section{Konsep Zakat}

Zakat adalah rukun Islam ketiga setelah syahadat dan shalat, begitu pentingnya zakat Allah swt. dalam al-Qur'an menyebut kata zakat sebanyak 30 kali dan 27 diantaranya beriringan dengan kata shalat ${ }^{3}$. Zakat mempunyai kedudukan yang sangat penting baik dalam konteks manusia dengan Allah, dengan dirinya, dengan masyarakat dan dengan hartanya. Jadi zakat adalah

\footnotetext{
${ }^{3}$ Apriliana, "Analisis Komparatif Antara Perlakuan Zakat Sebagai Pengurang Penghasilan Kena Pajak Dengan Perlakuan Zakat Sebagai Pengurang Langsung Pajak Penghasilan". Skripsi (Jakarta : Fak. Ekonomi dan Bisnis UIN Syarif Hidayatullah, 2010), h. 10.
} 
salah satu kewajiban dari Allah swt. Sesuai firman Allah SWT. QS Al-Baqarah $/ 2: 43$.

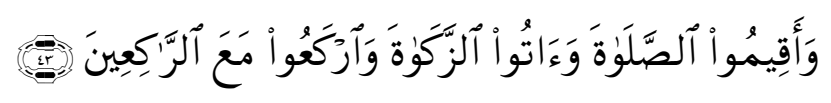

Terjemahnya :

Dan dirikanlah shalat, tunaikanlah zakat dan ruku'lah beserta orangorang yang ruku'.4

Ayat ini menunjukkan bahwa menunaikan zakat adalah sebuah perintah Allah yang berarti wajib untuk dilaksanakan, dan dengan menunaikkan zakat berarti telah memenuhi salah satu rukun Islam. Terdapat pula hadis yang menjelaskan kewajiban berzakat, seperti sabda Rasulullah Saw. artinya :

Abu Hurairah r.a. berkata bahwa seorang dusun datang kepada Nabi saw lalu berkata, "Tunjukkan kepadaku amal yang apabila saya amalkan, maka saya akan masuk surga." Beliau menjawab, "Kamu menyembah Allah, tidak menyekutukan-Nya dengan sesuatu pun, mendirikan shalat fardhu, menunaikan zakat yang diwajibkan, dan berpuasa pada bulan Ramadhan." Ia berkata, "Demi Zat yang diriku berada dalam genggamanNya (kekuasaan-Nya), saya tidak menambah atas ini." Ketika orang itu berpaling, Nabi saw bersabda, "Barangsiapa yang ingin melihat seseorang dari penghuni surga, maka lihat lah orang ini." (HR. Bukhari).

Hadis di atas memperjelas, zakat adalah suatu hal yang diwajibkan dan dalam hubungannya dengan diri sendiri (muzakki) merupakan salah satu cara memberantas pandangan hidup materialistis, suatu paham yang menjadikan harta bukan sebagai alat untuk mencapai tujuan hidup, tetapi menempatkannya sebagai tujuan hidup..

\section{Pengertian Zakat}

h. 7 .

${ }^{4}$ Departemen Agama RI, Mushaf Al-Qur'an dan Terjemah (Jakarta : Pustaka Al-Kautsar,2007), 
Kata zakat merupakan kata dasar dari zaka yang berarti berkah, tumbuh bersih dan baik. Menurut lisan al-arab kata zaka mengandung arti suci, tumbuh, berkah dan terpuji. Arti tumbuh dan suci tidak hanya di pakai untuk kekayaan saja, tetapi juga untuk jiwa orang yang berzakat. Sesuai firman Allah dalam Qs. At-Taubah/9 : 103. yang Terjemahnya :

Ambillah zakat dari sebagian harta mereka, dengan zakat itu kamu membersihkan dan mensucikan mereka dan berdoalah untuk mereka. Sesungguhnya doa kamu itu (menjadi) ketenteraman jiwa bagi mereka. dan Allah Maha mendengar lagi Maha mengetahui. ${ }^{5}$

Maksud ayat diatas adalah zakat itu membersihkan muzakki (orang yang berzakat) dari kekikiran dan cinta yang berlebihan kepada harta benda dan zakat itu menyuburkan sifat-sifat kebaikan dalam hati mereka dan memperkembangkan harta mereka. Pengertian zakat menurut syar'i dalam pandangan ahli fiqih Al-Syirbini, zakat sebagai nama bagi kadar tertentu dari harta benda tertentu yang wajib didayagunakan kepada golongan-golongan masyarakat tertentu. ${ }^{6}$ Ibrahim 'Usman asy-Sya'lan, zakat adalah memberikan hak milik harta kepada orang fakir yang muslim, Sayyid Sabiq, zakat adalah suatu sebutan dari suatu hak Allah yang dikeluarkan seseorang untuk fakir miskin.

\section{Hikmah Zakat}

Hikmah atau faedah zakat di bagi menjadi tiga bagian yaitu Faedah Diniyah, Faedah Khuluqiyyah, dan Faedah Ijtima'iyyah. ${ }^{7}$ Maksud dari ketiga faedah tersebut adalah sebagai berikut : Dari uraian mengenai hikmah zakat di atas, jika di lihat dari segi pengaruhnya dapat disimpulkan bahwa hikmah zakat memberi keuntungan kepada semua pihak. Bagi orang miskin, dana zakat itu akan mendorong dan memberi kesempatan untuk berusaha dan bekerja keras

\footnotetext{
${ }^{5}$ Departemen Agama RI, Mushaf Al-Qur'an dan Terjemah, h. 203

${ }^{6}$ Muhammad al-Syirbini, al-Iqna (Mesir: Musthafa al-Babi al-Halabi, 1940), h. 195

${ }^{7}$ Faedah Zakat", Wikipedia the free Encyclopedia. http://id.wikipedia.org/wiki/ Faedah_Zakat (18 Agustus 2014).
} 
sehingga gilirannya akan berubah dari golongan penerima zakat menjadi pemberi zakat..

\section{Konsep Pajak}

Pengertian pajak menurut P.J.A. Andriani, di kutip oleh Apriliana adalah:

Pajak merupakan iuran kepada negara (yang dapat dipaksakan) yang terhutang menurut peraturan perUndang-Undangan tanpa mendapat prestasi kembali yang langsung dapat ditunjuk dan digunakan untuk membiayai pengeluaran umum sehubungan dengan tugas negara untuk menyelenggarakan pemerintahan. ${ }^{8}$

Menurut Rochmat Soemitro dalam bukunya dasar-dasar hukum pajak dan pajak pendapatan yang di kutip oleh Apriliana :

Pajak adalah iuran rakyat kepada penguasa negara berdasarkan UndangUndang (yang dapat dipaksakan) dengan tidak mendapat jasa imbal (kontrprestasi) yang langsung dapat ditunjukkan dan yang digunakan untuk membayar pengeluaran umum.

Secara konstitusional pajak adalah salah satu sumber penerimaan negara yang sah dan dikukuhkan dalam UUD 1945 pasal 23A, yang menyebutkan bahwa, pajak dan pungutan lain yang bersifat memaksa untuk keperluan negara.

\section{Sistem Pemungutan Pajak}

Pemungutan pajak yang diterapkan tercermin dalam UU Pajak yaitu : official assessment system, semi self assessment system, self assessment system, dan withholding system ${ }^{9}$. Maksud UU pajak di atas ; Official Assesment System adalah suatu sistem pemungutan pajak yang memberi wewenang kepada pemungut

\footnotetext{
${ }^{8}$ Apriliana, “Analisis Komparatif Antara Perlakuan Zakat Sebagai Pengurang Penghasilan Kena pajak Dengan Perlakuan Zakat Sebagai Pengurang Langsung Pajak Penghasilan”, h. 31.

${ }^{9}$ Farid Wajdi, "Kajian Penerapan Zakat Sebagai Kredit Pajak Dalam Penghasilan Orang Pribadi di Indonesia”. Skripsi (Depok : Fak. Ilmu Sosial dan Ilmu Politik Universitas Indonesia, 2008),h. 45.
} 
pajak (fiskus) untuk menentukan besarnya pajak yang harus di bayar (pajak yang terhutang) oleh seseorang. Semi Self Assesment system adalah suatu sistem pemungutan pajak yang hampir sama dengan official assessment system. Sistem ini setiap tahun Wajib Pajak menentukan sendiri besarnya pajak yang terhutang untuk tahun berjalan Self Assessment System adalah suatu sistem pemungutan pajak yang memberi wewenang penuh kepada Wajib Pajak untuk menghitung, menyetorkan dan melaporkan sendiri besarnya utang pajak. Witholding System adalah suatu sistem pemungutan pajak yang memberi wewenang pada pihak ketiga untuk memungut besarnya pajak yang terutang.

\section{Penghasilan Kena Pajak}

Penghasilan Kena Pajak (PKP) adalah penghasilan Wajib Pajak yang menjadi dasar untuk menghitung pajak penghasilan ${ }^{10}$. Pendapatan kena pajak di atur Pasal 6 UU No. 7 Th 1983 tentang Pajak Penghasilan, telah di ubah dengan UU No. 36 Th 2008 tentang Perubahan keempat atas UU No. 7 Tahun 1983 tentang Pajak Penghasilan. PKP di dapat dengan menghitung penghasilan bruto dikurangi dengan biaya untuk mendapatkan, menagih dan memelihara peng-hasilan. Apabila dalam menghitung PKP, penghasilan bruto setelah dikurangkan dengan biaya untuk mendapatkan, menagih dan memelihara penghasilan di dapat kerugian maka kerugian tersebut dikompensasikan mulai dengan penghasilan tahun pajak berikutnya sampai dengan berturut-turut lima tahun.

Pengenaan Zakat untuk WPOP sebagai pengurang penghasilan Kena Pajak, hal ini sesuai dengan UU No. 36 Tahun 2008 Tentang Pajak Penghasilan dan UU No. 38 Tahun 1999 Tentang Pengelolaan Pajak. Formal pengenaan zakat yang digunakan untuk WPOP jika dikurangkan dari PKP. dirincikan dalam table:

\section{Table 2.4}

\footnotetext{
10 "Penghasilan Kena Pajak", Wikipedia the free Encyclopedia. http://id.wikipedia.org/wiki/ Penghasilan_Kena_Pajak (20 Agustus 2014).
} 
Formal Pengenaan Pajak dan Zakat untuk Wajib Pajak Orang Pribadi

\begin{tabular}{|c|c|c|}
\hline Gaji satu bulan & Rp. XXX & \\
\hline Tunjangan istri/anak & $X X X$ & \\
\hline Tunjangan perumahan & $X X X$ & \\
\hline Tunjangan pendidkan anak & $X X X$ & \\
\hline Tunjangan jabatan & $X X X$ & \\
\hline Tunjangan transport & $X X X$ & \\
\hline Jaminan kecelakaan kerja & $X X X$ & \\
\hline Jaminan kematian & $X X X$ & \\
\hline Jaminan pemelihara kesehatan & XXX & \\
\hline & & Rp. XXX \\
\hline Penghasilan Bruto (PB) & & \\
\hline Pengurang & & \\
\hline Biaya Jabatan $(5 \% \times P B)$ & $\underline{\text { Rp. }} X X X$ & \\
\hline Iuran Pensiun & $X X X$ & \\
\hline Iuran THT & $X X X$ & $\underline{\text { Rp. } X X X}$ \\
\hline Penghasilan neto sebulan & & Rp. XXX \\
\hline Penghasilan neto setahun & & Rp. XXX \\
\hline (-) Zakat $\mathrm{Ph}(2,5 \% \times \mathrm{PB}$ setahun) & & Rp. $(X X X)$ \\
\hline (-) PTKP & & $\underline{\operatorname{Rp}} \cdot(\mathrm{XXX})$ \\
\hline PKP & & Rp. XXX \\
\hline PPh 21 terhutang setahun & & Rp. XXX \\
\hline$(\mathrm{PKP} \times$ tarif pasal 17) & & \\
\hline
\end{tabular}

Sumber : Skripsi Apriliana, $2010: 44$

Tabel $2.1 \mathrm{di}$ atas menggambarkan cara menghitung pengenaan pajak dan zakat WPOP untuk mendapatkan bukti atau hasil diterapkannya zakat sebagai pengurang Penghasilan Kena Pajak setelah dikurangkan dengan Penghasilan 
Tidak Kena Pajak. Pengenaan Zakat untuk Wajib Pajak Orang Pribadi (WPOP) dikurangkan dari Penghasilan Kena Pajak, hal ini sesuai dengan UU No. 36 Tahun 2008 Tentang Pajak Penghasilan dan UU No. 36 Tahun 1999 Tentang Pengelolaan Zakat. Untuk penghasilan Tidak Kena Pajak (PTKP) per tahun sesuai dengan pasal 7 UU No. 36 Tahun 2008 Tentang Pajak Penghasilan adalah:

Tabel 2.3

Penghasilan Tidak Kena Pajak (PTKP)

\begin{tabular}{l|l}
\hline \multicolumn{2}{c}{ Besarnya Penghasilan Tidak Kena Pajak } \\
\hline Rp. 15.840.000 & Untuk diri Wajib Pajak Orang Pribadi (WPOP) \\
\hline Rp. 1.320.000 & Tambahan untuk Wajib Pajak menikah \\
\hline Rp. 15.840.000 & $\begin{array}{l}\text { Tambahan untuk seorang istri yang penghasilannya di } \\
\text { gabung dengan penghasilan suami }\end{array}$ \\
\hline Rp. 1.320.000 & $\begin{array}{l}\text { Tambahan untuk setiap anggota keluarga sedarah dan } \\
\text { keluarga semenda dalam garis keturunan lurus serta } \\
\text { anak angkat, yang menjadi tanggungan sepenuhnya, } \\
\text { paling banyak tiga orang untuk setiap keluarga. }\end{array}$ \\
\hline
\end{tabular}

Sumber : Undang-Undang Nomor 38 Tahun 2008

Tabel 2.3 di atas berisi tentang besarnya jumlah penghasilan yang tidak kena pajak (PTKP) dan aspek-aspeknya. Selain Penghasilan Tidak Kena Pajak, tarif pajak juga berpengaruh dalam perhitungan Zakat sebagai pengurang Penghasilan Kena Pajak, maka perlu di uraikan tarif pajak yang diterapkan atas Penghasilan Kena Pajak (PKP) bagi Wajib Pajak Orang Pribadi (WPOP). Rinciannya dapat dilihat dalam tabel sebagai berikut :

Tabel 2.4

Tarif Pajak Pasal 17 


\begin{tabular}{l|c}
\hline \multicolumn{1}{c|}{ Lapisan PKP } & Tarif Pajak \\
\hline Sampai dengan Rp. 50.000.000 & $5 \%$ \\
\hline Diatas Rp. 50.000.000 s/d Rp. 250.000.000 & $15 \%$ \\
\hline Diatas Rp. 250.000.000 s/d Rp. 500.000.000 & $25 \%$ \\
\hline Diatas Rp. 500.000.000 & $30 \%$ \\
\hline
\end{tabular}

Sumber : Undang-Undang Nomor 36 Tahun 2008

\section{Pajak dalam Pandangan Islam}

Menurut Ilfi yang di kutip oleh Sri Andriani dan Fatha Fathya pada jurnalnya bahwa dalam peradaban Islam di kenal dua lembaga yang menjadi pilar kesejahteraan masyarakat dan kemakmuran negara yaitu Lembaga Zakat dan Lembaga Pajak karena sifatnya adalah wajib. Pada prinsipnya zakat dan pajak adalah dua kewajiban yang mempunyai dasar berpijak berlainan. Zakat mengacu pada ketentuan syariat Islam, sedangkan pajak berpijak pada peraturan perundang-undangan yang ditentukan oleh Ulil Amri (pemerintah) menyangkut pemungutan maupun penggunaannya. Ummat Islam sejak abad pertama hijriyah telah mengenal pajak dengan sebutan kharaj (pajak hasil bumi/tanaman), sedang pajak dalam pengertian umum disebut dharibah. Dalam Islam pajak terdiri atas Kharaj (pajak bumi/tanaman), Usyur (pajak perdagangan/bea cukai), dan Jizyah (pajak jiwa terhadap non-muslim yang hidup di dalam naungan pemerintahan Islam).

\section{Hubungan Antara Zakat Dengan Pajak}

Zakat dan pajak berkorelasi satu sama lain, namun keduanya berbeda dalam beberapa hal. Di antara titik persamaan antara zakat dan pajak adalah sama-sama bersifat memaksa, melibatkan pengelola dan tujuan kesejahteraan bersama. Seorang muslim yang mampu wajib mendistribusikan kekayaannya melalui penyaluran zakat dijelaskan dalam QS. At-Taubah/9:103. yang Terjemahnya :

Ambillah zakat dari sebagian harta mereka, dengan zakat itu kamu membersihkan dan mensucikan mereka dan berdoalah untuk mereka. 
Sesungguhnya doa kamu itu (menjadi) ketenteraman jiwa bagi mereka. dan Allah Maha mendengar lagi Maha mengetahui. ${ }^{11}$

Sebagaimana disebutkan bahwa zakat membersihkan dan mensucikan orang-orang yang menunaikan zakat. Kewajiban Zakat ini juga di kemukakan dalam sebuah hadis yang diriwayatkan oleh Abu Dawud bahwa ketika banyak orang mengingkari kewajiban zakat di zaman Abu Bakar As-siddiq, Beliau berkata : Demi Allah, saya akan memerangi orang yang memisahkan kewajban sholat dengan kewajiban zakat. Sesungguhnya zakat itu hak yang terkait dengan harta. Demi Allah, jika mereka menolak mengeluarkan zakat unta yang biasa mereka tunaikan kepada Rasulullah Saw, pasti aku akan memeranginya, karena penolakan tersebut. ${ }^{12}$

Tujuan zakat dan pajak adalah untuk menekan kesenjangan sosial ekonomi dalam masyarakat dan melakukan pemerataan harta kepemilikan untuk kesejahteraan bersama ${ }^{13}$. Zakat dan Pajak keduanya mengandung beberapa aspek perbedaan, yaitu pada sisi penamaan, dasar hukum dan sifat kewajiban. Dari segi penamaan, zakat berarti bersih, suci, berkah, tumbuh, maslahat, dan berkembang. Sementara pajak, berasal dari kata dharibah yang secara etimologis berarti beban dan kadangkala diartikan pula dengan jizyah yang berarti pajak tanah (upeti) yang diserahkan oleh ahli zimmah (orang yang tetap dalam kekafiran tetapi tunduk pada aturan pemerintah Islam).

\section{Persamaan Zakat dengan Pajak}

Berdasarkan penjelasan di atas, persamaan antara zakat dengan pajak Unsur paksaan dan kewajiban yang merupakan cara untuk menghasilkan pajak, juga terdapat dalam zakat. Bila pajak harus di setor kepada negara, pusat maupun daerah, maka zakatpun demikian. Karena pada dasarnya zakat itu

\footnotetext{
${ }^{11}$ Departemen Agama RI, Mushaf Al-Qur'an dan Terjemah, h. 204.

${ }^{12}$ Ahmad bin 'Ali bin hajar al-Asqalani, Bulugh al-Maram min 'Adillah al-'ahkam (bairut : Dar al-Fikr, 2001), h.114

${ }^{13}$ Sjechul Hadi Permono, "Pendayagunaan Zakat disamping Pajak dalam Rangka Pembangunan Nasional”, Disertasi,(Jakarta : IAIN Syarif Hidayatullah, 1988), h. 119.
} 
harus diserahkan kepada pemerintah sebagai badan yang disebut LAZ atau BAZ. Pada ketentuan pajak tidak ada imbalan tertentu. Para wajib pajak menyerahkan pajaknya selaku anggota masyarakat. Ia hanya memperoleh berbagai fasilitas untuk dapat melangsungkan kegiatan usahanya. Pajak pada zaman modern ini mempunyai tujuan ke masyarakat, ekonomi dan politik di samping tujuan keuangan, maka zakat mempunyai tujuan yang lebih jauh dan jangkauan yang lebih luas dari pada aspek-aspek tersebut. ${ }^{14}$

\section{Perbedaan Zakat dengan Pajak}

Perbedaan zakat dengan pajak menurut beberapa ahli. Dari segi nama dan etiketnya, Perbedaan antara zakat dan pajak sepintas lalu Nampak dari etiketnya, baik arti maupun kiasannya. Dari segi hakikatnya, Zakat adalah ibadah dan merupakan rukun islam sehingga pembayarannya tidak sah jika tidak diikuti dengan niat. Dari segi batas dan ketentuannya

\section{METODE PENELITIAN}

\section{Jenis dan Lokasi Penelitian}

Penelitian ini menggunakan metode penelitian kualitatif yang bersifat dekriptif dan cenderung menggunakan analisis dengan pendekatan induktif. Proses dan makna (prespektif subyek) lebih ditonjolkan. Sifat dari jenis penelitian ini adalah penelitian dan penjajahan terbuka berakhir dilakukan dalam jumlah

\footnotetext{
${ }^{14}$ Apriliana, “Analisis Komparatif Antara Perlakuan Zakat Sebagai Pengurang Penghasilan Kena pajak Dengan Perlakuan Zakat Sebagai Pengurang Langsung Pajak Penghasilan”,h. 45-46.
} 
relatif kelompok kecil yang diwawancarai sacara mendalam. Responden di minta untuk menjawab pertanyaan umum dan menentukan persepsi, pendapat dan perasaan tentang gagasan atau topik yang di bahas dan untuk menentukan arah penelitian. Lokasi Penelitian sesuai dengan judul, maka penelitian ini berlokasi di Kantor Kementrian Agama Kabupaten Gowa. Jl. K.H Agussalim No. 3 Sungguminasa-Gowa. Pendekatan Penelitian Pendekatan penelitian yang dilakukan adalah Pendekatan Normatif dan Pendekatan Sosiologis. Peneliti melakukan pendekatan normatif karena isi penelitian banyak berkaitan dengan teks-teks Al-Qur'an, dan pendekatan sosiologis karena peneliti melakukan interaksi lingkungan sesuai dengan unit sosial, individu, kelompok dan lembaga.

\section{Sumber Data}

Data Primer Kepala Seksi Bimbingan Islam Kementerian Agama Kabupaten Gowa yang mengatur urusan-urusan agama Islam seperti Ibadah sosial, Pangan halal, Pengelolaan Zakat, Infaq dan Sedekah (ZIS) dan lain-lain. Kepala Keuangan Kementerian Agama Kabupaten Gowa, yang mengatur tentang gaji dan biaya-biaya terkait. Bendahara Keuangan Kementerian Agama Kabupaten Gowa, yang mengatur keuangan yang dikenai zakat dan pajak. Data Sekunder Data sekunder adalah data yang diperoleh melalui penulusuran berbagai referensi yang terkait penerapan zakat sebagai pengurang Penghasilan Kena Pajak. Adapun data sekunder tersebut berupa dokumenter atau sumbersumber tertulis. Seperti majalah, buku-buku, Koran, laporan penelitian dan sebagainya. Metode Pengumpulan Data Data yang dibutuhkan dalam penelitian ini secara umum terdiri dari data yang bersumber dari penelitian lapangan. Adapun metode pengumpulan data yang digunakan dalam penelitian ini adalah sebagai berikut Observasi, Dokumentasi, Wawancara.

\section{HASIL PENELITIAN DAN PEMBAHASAN}

\section{Ketentuan Zakat dalam Undang-Undang Perpajakan}

Reformasi peraturan perpajakan mengenai zakat dilakukan oleh pemerintah untuk mendorong wajib pajak dan muzakki agar dapat 
menunaikan kewajiban membayar pajak penghasilan dan zakat penghasilan dengan baik. Untuk mengatasinya pemerintah telah melakukan integralisasi antara kewajiban pajak dan zakat. Pada Pasal 9 ayat (1) huruf g UndangUndang Nomor 36 Tahun 2008 tentang Pajak penghasilan telah mengkomodir zakat bahwa:

Untuk menentukan besarnya Penghasilan Kena Pajak bagi Wajib Pajak dalam dalam negeri dan bentuk usaha tetap tidak boleh dikunrangkan dari harta yang dihibahkan, bantuan atau sumbangan dan warisan, kecuali sumbangan sebagaimana dimaksud dalam pasal 6 ayat (1) huruf I sampai m serta zakat yang di terima oleh Badan Amil Zakat atau Lembaga Amil Zakat yang di bentuk atau disahkan oleh pemerintah atau sumbangan keagamaan yang sifatnya wajib bagi pemeluk agama yang diakui di Indonesia, yang di terima oleh lembaga keagamaan yang di bentuk atau disahkan oleh pemerintah.

Termaktub pula dalam Pasal 14 ayat (3) Undang-Undang Nomor 38 Tahun 1999 Tentang pengelolaan Zakat menyatakan bahwa:

Zakat yang telah dibayarkan kepada Badan Amil Zakat atau Lembaga Amil Zakat dapat dikurangkan dari laba atau pendapatan sisa kena pajak dari wajib pajak yang bersangkutan.

Dari kedua undang-undang ini dapat disimpulkan bahwa perlakuan zakat yang berlaku di Indonesia saat ini yaitu zakat sebagai pengurang Penghasilan Kena Pajak (PKP). Selama ini di kalangan ummat islam beredar anggapan yang salah, bahwa membayar zakat dapat langsung mengurangi pajak yang akan di bayar. Namun sesungguhnya tidak, sebagaimana keputusan Dirjen pajak Nomor KEP-163/PJ/2003 bahwa :

Zakat atas penghasilan yang nyata-nyata dibayarkan oleh Wajib Pajak orang pribadi dalam negeri pemeluk agama islam dan atau Wajib Pajak badan dalam negri yang dimiliki oleh pemeluk agama Islam kepada Badan Amil Zakat atau Lembaga Amil Zakat yang di bentuk atau disahkan oleh pemerintah sesuai ketentuan Undang-Undang Nomor 38 Tahun 1999 tentang Pengelolaan Zakat, boleh dikurangkan dari penghasilan bruto Wajib Pajak badan atau penghasilan neto Wajib Pajak 
orang pribadi yang bersangkutan dalam menentukan besarnya Penghasilan Kena Pajak.

KEP di atas menegaskan kembali ketentuan yang di atur dalam UU No. 38 Tahun 1999 serta UU No. 36 Tahun 2008 yang menyatakan bahwa zakat yang dibayarkan dapat dikurangi dari penghasilan neto wajib pajak orang pribadi. Maksud wajib pajak orang pribadi yang membayar zakat penghasilan, zakat tersebut diperbolehkan menjadi deductible expense (dapat dijadikan biaya). Maka jika penghasilan neto seorang Wajib Pajak orang pribadi adalah Rp. 5.000.000 sedangkan Wajib Pajak tersebut telah menunaikan zakat sebesar 1.000.000, pajak yang harus di bayar adalah Rp. 4.000 .000 (Rp. 5.000.0001.000.000) dikalikan tarif progresifnya sebesar $5 \%$ yaitu 200.000 .

Meskipun zakat penghasilan dapat diakui sebagai pengurang Penghasilan Kena Pajak, namun bila di tinjau lebih dalam Undang-Undang Nomor 36 Tahun 2008, maka untuk melaporkan zakat penghasilan sebagai pengurang Penghasilan Kena Pajak, Wajib Pajak harus memenuhi beberapa persyaratan yang sifatnya komulatif yang harus dicantumkan dalam laporan pajak penghasilan tahunan (SPT Tahunan PPh), diantaranya yaitu : Zakat harus nyata-nyata dibayarkan oleh Wajib Pajak orang pribadi dalam negeri pemeluk agama Islam dan atau Wajib Pajak badan dalam negeri yang dimiliki oleh pemeluk agama Islam. Zakat yang dibayarkan kepada Badan Amil Zakat atau Lembaga Amil Zakat yang di bentuk atau disahkan oleh pemerintah sebagaimana yang di atur dalam UU No. 38 tahun 1999 tentang pengelolaan Zakat. Dari pembayaran zakat tersebut akan dibuatkan Nomor Pokok Waji Zakat (NPWZ) dan Bukti Setor Zakat (BSZ) yang diberikan kepada muzakki dan nantinya digunakan sebagai bukti pengurang PPh. Namun dalam struktur masyarakat Indonesia, keberadaan amil zakat yang berada disekitar mereka seperti Lembaga amil Zakat yang di kelola masjid atau mushallah maupun yayasan swadaya masyarakat, jumlahnya lebih banyak daripada badan atau lembaga resmi pemerintah. Zakat yang dibayarkan adalah zakat yang berkenaan dengan penghasilan yang merupakan objek pajak yang dikenakan 
pajak penghasilan yang tidak bersifat final. Jadi jika kita membayar zakat atas penghasilan dari bunga deposito, hadiah undian, transaksi saham dan transaksi pengalihan harta maka zakat penghasilan yang kita bayarkan tersebut tidak dapat diakui sebagai pengurang pajak penghasilan. Sesuai Keputusan Dirjen Pajak Nomor KEP-163/PJ./2003 ketentuan zakat sebagai pengurang Penghasilan Kena Pajak baru merupakan zakat penghasilan saja. Ini tidak berlaku untuk sejumlah jenis zakat.

\section{Penerapan Zakat Sebagai Pengurang Penghasilan Kena Pajak}

Kebijakan Zakat sebagai pengurang Penghasilan Kena Pajak di atur dalam UU Republik Indonesia No. 36 Tahun 2008 tentang Pajak Penghasilan dan UU No. 23 Tahun 2011 Perubahan atas UU No. 38 Tahun 1999 Tentang Pengelolaan Zakat serta Keputusan Direktur Jendral Pajak dengan Nomor KEP163/PJ/2003 mengenai Perlakuan Zakat dikurangkan dari Penghasilan dalam Penghitungan Penghasilan Kena Pajak atas Pajak Penghasilan.

Mengenai pelaksanaan pengelolaan zakat tentunya tidak dapat dipisahkan dari sebuah ukuran akan berhasil atau tidaknya pengelolaan zakat tersebut. Keberhasilan dalam pengelolaan zakat di tentukan dari strategi dan manfaat zakat bagi mustahiq. Keberhasilan pengelolaan zakat dapat dilihat dari adanya perubahan peran seseorang, dari yang awalnya menjadi mustahiq berdaya dan beralih menjadi seorang Muzzaki. Untuk merubah peran seseorang mustahiq dari yang di bantu menjadi yang membantu (muzzaki) dalam zakat ditentukan oleh strategi dan program pendistribusian yang dilakukan oleh pengelola Zakat. Pengelolaan zakat menjadi suatu hal yang penting karena keberhasilan ini hanya dapat dicapai dengan pola pengelolaan zakat secara efektif produktif .

Pengelolaan zakat di Kantor Kementerian Agama Kabupaten Gowa muncul atas kesadaran sendiri dari pihaknya sebagai Muslim. Zakat yang di kelola adalah zakat penghasilan. Sebagai pemerintah, pengambilan zakat ini 
dilakukan oleh pihak Kementerian Agama sebagai contoh untuk masyarakat dalam memenuhi atau menunaikan kewajiban kepada Allah swt.

Kementerian Agama Kabupaten Gowa telah menerapkan kebijakan pemerintah tentang zakat sebagai pengurang Penghasilan Kena Pajak sejak dikeluarkannya Undang Nomor 38 Tahun 1999 Tentang Pengelolaan Zakat sebagaimana telah di ubah terakhir dalam pasal 22 Undang-Undang Nomor 23 Tahun 2011. Melaksanakan suatu tugas dari pimpinan atau pemerintah termasuk juga suatu kewajiban. Dan sebagai lembaga pemerintah, Kementerian Agama pasti mementingkan kemaslahatan ummat.

Menurut Kepala Seksi Bimbingan Islam (BIMAS) yang telah di wawancarai oleh peneliti, Walaupun zakat dan pajak tidak dapat disamakan karena pajak adalah kewajiban dari negara sedangkan zakat adalah kewajiban dari Allah swt, tetapi dalam rangka untuk kebaikan ummat maka akan tetap dilaksanakan, lagi pula dalam hal ini tidak ada pihak yang akan dirugikan. ${ }^{15}$

Penerapan zakat sebagai pengurang penghasilan kena pajak telah disosialisasikan oleh kementerian agama dengan pengurus-pengurus zakat lainnya yang ada di wilayah kabupaten gowa. Hal ini terlihat dalam kegiatan "Orientasi Pengurus UPZ" yang dilaksanakan oleh Kementerian Agama Kabupaten Gowa. Dalam kegiatan ini pihak Kementerian Agama menghadirkan Ketua Majelis Ulama Kabupaten Gowa KH. Abubakar Paka sebagai pemateri fiqhi zakat, Kepala Kantor Kementerian Agama Kabupaten Gowa H. Jamaris sebagai pemateri kebijakan pemerintah dalam pengelolaan zakat dan Kepala Seksi Bimbingan Islam Kementerian Agama Kabupaten Gowa H. Mujahid Dahlan sebagai pemateri motivasi zakat. Orientasi pengurus Unit Pengumpul Zakat (UPZ) ini diikuti oleh oleh 25 orang UPZ dari beberapa instansi dan lembaga zakat di Kabupaten Gowa.

\section{Pemanfaatan Zakat di Kementerian Agama Kabupaten Gowa.}

\footnotetext{
${ }^{15}$ Mujahid Dahlan (42 tahun), Kepala Seksi Bimbingan Islam kantor Kementerian Agama Kabupaten Gowa, Wawancara, Gowa, 24 Februari 2015.
} 
Pemanfaatan zakat terbagi 2 aspek yaitu aspek sosial dan aspek ekonomi. Aspek sosial adalah menyalurkan dana zakat tersebut untuk kemaslahatan pribadi dan kemaslahatan umum. Sedangkan dalam segi ekonomi adalah bahwa harta berputar di antara masyarakat, dan bahwa zakat adalah daya dorong untuk perputaran harta benda dalam masyarakat dan menjadi salah satu sumber dana Baitul Mal. ${ }^{16}$

Pemanfaatan zakat di Kementerian Agama Kabupaten Gowa disalurkan dengan aspek sosial. Zakat yang telah dikumpulkan langsung dibagikan kepada golongan penerima zakat yang berada di wilayah Kementerian Agama Kabupaten Gowa, seperti : memberikan kepada panti asuhan, janda dan pihakpihak yang kurang mampu lainnya.

\section{Perhitungan Zakat sebagai pengurang Penghasilan Kena Pajak di Kementerian Agama Kabupaten Gowa}

Perhitungan zakat dan pajak sangat mempengaruhi penghasilan, oleh karena itu perhitungan harus dipahami dengan benar. Berikut penulis uraikan perhitungan penerapan zakat sebagai pengurang Penghasilan Kena Pajak, sebagai contoh dari rata-rata gaji pegawai di Kantor Kementerian Agama: Tuan A seorang muslim dan bekerja sebagai pegawai di Kantor Kementerian Agama Kabupaten Gowa mendapatkan gaji Rp. 4.500 .000 tiap bulan. Ia tidak memiliki penghasilan lain dan belum menikah, sehingga perhitungan PPh pasal 21 terhutang tahun 2014 adalah sebagai berikut :

${ }^{16}$ Syehul Hadi Permono, Sumber-sumber penggalian zakat (Jakarta : Pustaka Firdaus, 1992),h. 
Thamrin: Zakat; pengurang; pajak

Tabel 1.1

Perhitungan Zakat dan Pajak di Kementerian Agama Kabupaten Gowa

\begin{tabular}{l|lr}
\hline ghasilan Bruto setahun & Rp. & 54.000 .000 \\
(-)Biaya jabatan (5\% x Ph Bruto) & Rp. & 2.700 .000 \\
Penghasilan Neto Setahun & Rp. & 51.300 .000 \\
(-) Zakat (2,5\% x Ph Bruto) & Rp. & 1.350 .000 \\
& \multicolumn{2}{|l}{} \\
Penghasilan Neto Setelah Zakat & Rp. & 49.950 .000 \\
(-) PTKP (TK/0) & Rp. & 15.840 .000 \\
PKP & Rp. & 34.110 .000 \\
PPh 21 terutang (5\% x PKP) & Rp. & $\mathbf{1 . 7 0 5 . 5 0 0}$ \\
& \multicolumn{2}{|l}{} \\
\hline
\end{tabular}

Sumber : Kementerian Agama Kabupaten Gowa

Dari presentase masing-masing zakat dan pajak yang dikeluarkan jika zakat dijadikan sebagai pengurang Penghasilan Kena Pajak (PKP) adalah sebagai berikut :

Tabel 1.2

Persentase Pajak dan Zakat sebagai Pengurang PKP

\begin{tabular}{c|c|c|c}
\hline Pajak & Zakat & Total & Penghasilan \\
\hline Rp. 1.705.000 & Rp. 1.350.000 & Rp. 3.055.500 & Rp. 54.000.000 \\
\hline $3,16 \%$ & $2,5 \%$ & $5,66 \%$ & $100 \%$ \\
\hline
\end{tabular}

Dari tabel 4.1 di atas, dapat dilihat bahwa zakat yang dikeluarkan sebesar R. 1.350.000 dan Pph 21 terutang yang di tanggung tuan A adalah sebesar Rp. 1.705.500. Sesuai ketentuan pasal 1 ayat 3 Keputusan Direktur Jenderal Pajak Nomor KEP-163/PJ/2003, dalam perhitungan penghasilan kena 
pajak bahwa beasarnya zakat yang dapat dikurangkan dari penghasilan kena pajak adalah sebesar 2,5 persen dari jumlah penghasilan kena pajak.

\section{Harapan Kementerian Agama Kabupaten Gowa mengenai pengelolaan zakat di masa yang akan datang.}

Kedudukan zakat yang pertanggungjawabannya langsung kepada Allah swt. menjadikan Muzakki tetap membayar zakat walaupun mempunyai beban ganda yaitu dengan kewajiban pembayaran pajak (5 persen dari penghasilan bruto) dan kewajiban pembayaran zakat (2,5 persen dari penghasilan bruto). Namun, jika ada cara untuk meringankan masyarakat dalam membayar zakat dan pajak maka akan sangat efektif.

Zakat sebagai pengurang penghasilan kena pajak di nilai masih memberakan wajib pajak yang beragama islam karena tetap mempunyai kewajiban ganda. Karenanya Pihak Kementerian Agama Kabupaten Gowa berharap bahwa pengelolaan zakat kedepannya dapat lebih meringankan beban masyarakat muslim. Seperti halnya usulan BAZNAS tentang pengelolaan zakat yang di laksanakan di Malaysia yaitu dengan zakat sebagai pengurang langsung pajak penghasilan (kredit pajak). Pengalaman penerapan kebijakan zakat sebagai kredit pajak yang diterapkan di Malaysia menunjukkan bahwa kebijakan kredit pajak ini dapat menjadi pemicu meningkatnya pendapatan di kedua instrumen tersebut secara bersamaan. Berikut penulis ilustrasikan sebagai contoh jika zakat sebagai pengurang langsung pajak penghasilan (kredit pajak).

Tuan A seorang muslim dan bekerja sebagai pegawai di Kantor Kementerian Agama Kabupaten Gowa mendapatkan gaji Rp. 4.500.000 tiap bulan. Ia tidak memiliki penghasilan lain dan belum menikah, sehingga perhitungan PPh pasal 21 terhutang tahun 2014 adalah sebagai berikut : 
Tabel 1.3

Zakat Sebagai Pengurang Langsung PPh (Kredit Pajak)

\begin{tabular}{l|lr}
\hline $\begin{array}{l}\text { Penghasilan Bruto setahun } \\
\text { (-)Biaya jabatan }(5 \% \times \text { Ph Bruto) }\end{array}$ & Rp. & 54.000 .000 \\
Penghasilan Neto Setahun & 2.700 .000 \\
(-) PTKP $($ TK $/ 0)$ & Rp. & 51.300 .000 \\
& Rp. & 15.880 .000 \\
PKP & Rp. & 35.460 .000 \\
PPh 21 terutang $(5 \% \times$ PKP) & Rp. & 1.773 .000 \\
(-) Zakat $(2,5 \% \times$ Ph Bruto) & Rp. & 1.350 .000 \\
& \multicolumn{2}{|l}{} \\
PPh 21 terutang & Rp. & $\mathbf{4 2 3 . 0 0 0}$ \\
\hline
\end{tabular}

Sumber : Data diolah sendiri

Dan persentase masing-masing zakat dan pajak yang dikeluarkan jika zakat dijadikan sebagai pengurang langsung pajak penghasilan (kredit pajak) sebagai berikut :

Tabel 4.4

Persentase Zakat dan Pajak sebagai pengurang langsung PPh (Kredit Pajak)

\begin{tabular}{|c|c|c|c|}
\hline Pajak & Zakat & Total & Penghasilan \\
\hline Rp. 423.000 & Rp. 1.350 .000 & Rp. 1.773 .000 & Rp. 54.000 .000 \\
\hline $0,78 \%$ & $2,5 \%$ & $3,28 \%$ & $100 \%$ \\
\hline
\end{tabular}

Pada perlakuan zakat sebagai pengurang langsung Pajak Penghasilan (Kredit Pajak), dapat di lihat bahwa pajak terutang Rp.1.773.000 dikurangi dengan zakat (sebagai kredit pajak) yang dikeluarkan sebesar 1.350.000, sehingga pajak yang dibayar dapat ditekan sebesar Rp. 423.000. Dari 
perhitungan presentase tabel $4.4 \mathrm{di}$ atas berdasarkan perhitungan pajak penghasilan, jumlah pajak dan zakat yang di bayar tuan A dalam tahun 2014 adalah Rp. 1.773 .000 dari penghasilan setahun atau 3,28 persen dari 100 persen penghasilan. Hasil analisis dari kasus Tuan A (tabel 4.1 dengan tabel 4.3) di atas, dapat dilihat kurang efektifnya zakat sebagai pengurang penghasilan kena pajak, maka perlakuan tersebut kurang tepat. Adanya kesetaraan filosofis antara zakat penghasilan dan pajak penghasilan yang menciptakan aspek kongruensi, maka tentunya akan menimbulkan beban ganda. Untuk menyelaraskan aspek filosofis dan menghindari beban ganda serta menciptakan keadilan maka perlakuan zakat sebagai pengurang langsung pajak (kredit pajak) dapat dikatakan tepat.

\section{PENUTUP}

\section{Kesimpulan}

Zakat sebagai pengurang Penghasilan Kena Pajak di Kantor Kementerian Agama Kabupaten Gowa memberikan keringanan kepada ummat Islam dalam membayar zakat dan pajak juga meningkatkan kesadaran dan kejujuran dalam diri masyarakat untuk membayar zakat, dengan kesadaran masyarakat membayar zakat dan pajak maka akan semakin meningkat muzakki dan sudah tentu akan meningkatkan pendapatan negara.

\section{Implikasi Penelitian}

Berdasarkan hasil penelitian pada bab sebelumnya, maka implikasi penelitian ini adalah BAZNAS diharapkan agar melakukan penelitian dan kajian yang komprehensif atas usulannya yang menyatakan zakat dapat dijadikan sebagai kredit pajak atau zakat sebagai pengurang langsung pajak penghasilan untuk disosialisasikan kepada berbagai pihak termasuk anggota legislatif dan pemerintah, untuk meningkatkan pemahaman akan pentingnya kebijakan ini. Bagi pemerintah, dengan adanya usulan perlakuan zakat sebagai 
pengurang langsung pajak penghasilan (kredit pajak) ini seharusnya dapat dijadikan perhatian dalam merevisi Undang-Undang Nomor 22 Tahun 2011 Tentang Pengelolaan Zakat. Yang perlu diperhatikan yaitu ketika masalah pajak telah di revisi dalam undang-undang zakat, maka pelaksanaannya harus di atur pula dalam undang-undang pajak sehingga pengaplikasiannya akan berjalan lebih baik. Perlu ada payung hukum yang jelas jika zakat memang benar-benar diterapkan sebagai pengurang langsung pajak penghasilan. Payung hukum itu nantinya juga harus memperhatikan wajib pajak yang tidak membayar zakat (non muslim). Apakah sumbangan keagamaan serupa dalam agama lain akan diperlakukan sama dengan wajib zakat yang membayar pajak. Dan yang terpenting adalah harus ada standar manajemen yang jelas bagi pengelolaan zakat di negara Indonesia. Menjadi suatu kesyukuran jika skripsi ini dapat menjadi suatu rujukan, contoh, dan bahan bacaan untuk menambah dan memperluas wawasan tentang zakat dan pajak. 


\section{DAFTAR PUSTAKA}

Andriani, Sri dan Fatha Fathya, "Zakat Sebagai pengurang Pajak Penghasilan Pada Badan Amil Zakat", UIN Maulana Malik Ibrahim, vol. 4, (Februari 2013) : h. 16-

al-Asqalani, Ahmad bin 'Ali bin hajar. Bulugh al-Maram min 'Adillah al-'ahkam.

Bairut : Dar al-Fikr, 2001.

Bungin, Burhan. Penelitian Kualitatif, Jakarta: Kencana. 2009.

Damanhur, Mewujudkan Sistem Perpajakan Perspektif Islam. Banda Aceh Darussalam : Prosiding Persidangan Antar bangsa Pembangunan Aceh. 2006.

Departemen Agama RI, Al-Qur'an dan Terjemahan, Jakarta : Pustaka Al-kautsar. 2007.

"Faedah Zakat", Wikipedia the free Encyclopedia. http://id.wikipedia.org/wiki/ Faedah_Zakat (18 Agustus 2014).

Farid, Muhammad. "Zakat dan Pajak untuk Kesejahteraan : Dualisme Aturan Zakat dan Pajak di Indonesia", STAIN Watampone, Vol. 18 No.1 (2012) : Ibrahim, Teuku H. Muslim. Hubungan Antara Zakat dan Pajak Sebagai Sumber Dana Kemasyarakatan. Jakarta : PT Bina Rena Pariwara. 1992.

Indonesian Tax Review. Vol IV, Ed 47. 2007.

al-Kindi, Bamz. "Hubungan antara zakat dengan pajak meneurut pandangan islam"(19 Desember 2011),

Keputusan Direktur Jenderal Pajak Nomor KEP-163/PJ/2003 pasal 1 ayat (3).

"Pajak Penghasilan", Wikipedia the free Encyclopedia. http://id.wikipedia.org/wiki/ Pajak_Penghasilan, (16 Oktober 2014).

"Penghasilan Kena Pajak", Wikipedia the free Encyclopedia. http://id.wikipedia.org/wiki/ Penghasilan_Kena_Pajak, (20 Agustus 2014).

Permono, Sjechul Hadi, "Pendayagunaan Zakat disamping Pajak dalam Rangka Pembangunan Nasional," Disertasi, IAIN Syarif Hidayatullah Jakarta, 1988.

-------, “Sumber-Sumber Penggalian Zakat. Jakarta : Pustaka Firdaus, 1992.

Rahmawati Muin, Manajemen Zakat. Samata : Alauddin Universsity Press, 2011.

Republik Indonesia. Undang-Undang Nomor 23 Tahun 2011 Tentang Pengelolaan Zakat. 
Thamrin: Zakat; pengurang; pajak

Republik Indonesia. Undang-Undang Nomor 38 Tahun 1999 tentang Pengelolaan Zakat pasal 14 ayat 3.

${ }^{1}$ al-Syirbini, Muhammad. al-Iqna. Mesir: Musthafa al-Babi al-Halabi.1940

Usman, Husain dan Purnomo Setiady Akbar, Metodologi Penelitian Sosial, Cet. IV. Jakarta: PT. Bumi Aksara, 2001.

'Usman asy-Syar'lan, Ibrahim . Nizhamu Misa fi al-Zakah wa Tauzi'u al-Ghana'im . Riyad: Tp, 1981.

Uzaifah, "Manajemen Zakat Pasca Kebijakan Pemerintah Tentang Zakat Sebagai Pengurang Penghasilan Kena Pajak". Vol.4 No. 1 (Juli 2010), h. 4849. http://www.google.com /jurnals.files.wordpress.com/ uzaifah2010.pdf.

Wajdi, Farid. "Kajian Penerapan Zakat Sebagai Kredit Pajak Dalam Penghasilan Orang Pribadi di Indonesia". Skripsi . Depok : Fakultas Ilmu Sosial dan Ilmu Politik Universitas Indonesia. 2008. 